\title{
Protopectinus pseudoparatinus - a new genus and species of soft winged flower beetle of the tribe Apalochrini (Coleoptera: Malachiidae) from East Africa
}

\section{Protopectinus pseudoparatinus - новый виА и род жкуков малашек трибы Apalochrini (Coleoptera: Malachiidae) из Восточной Африки}

\author{
S.E. Tshernyshev \\ С.Э. Чернышёв
}

\author{
Institute of Animal Systematics and Ecology, Russian Academy of Sciences, Siberian Branch, Frunze Street 11, Novosibirsk 630091, \\ Russia. E-mail: sch-sch@mail.ru \\ Tomsk State University, Lenina prospekt 36, Tomsk 634050, Russia. \\ Институт систематики и экологии животных СО РАН, ул. Фрунзе 11, Новосибирск 630091, Россия. \\ Томский государственный университет, проспект Ленина 36, Томск 630050, Россия.
}

KEY WORDS: Coleoptera, Malachiidae, Apalochrini, Protopectinus, pseudoparatinus, new genus, new species, Tanzania, East Africa

КЛЮЧЕВЫЕ СЛОВА: Coleoptera, Malachiidae, Apalochrini, Protopectinus, pseudoparatinus, новый вид, новый род, Танзания, Восточная Африка

ABSTRACT. A new genus and species, Protopectinus pseudoparatinus gen. et sp.n., is described in the tribe Apalochrini (Coleoptera: Malachiidae) from Tanzania, East Africa. The species looks similar to Eurasian Apalochrus Er. (former Paratinus Abeille de Perrin), but differs in presence of a comb on second segment of anterior tarsi in male. Amongst Apalochrini congeners possessing tarsal comb the new species is most close to Protapalochrus Evers due to male special characters which are weakly pronounced. From the latter genus the new species differs in special male characters as follows: antenna slightly serrate, $1^{\text {st }} 2^{\text {nd }}$ tarsomeres enlarged in comparison with remaining ones in all legs, anterior tibiae slightly widened distally whereas intermediate swollen and with flat straight area along the inner side possessing glands of pheromones. A new genus, Protopectinus gen.n., is described on the basis of characters mentioned above. External appearance, special characters and genitalia of male of the new species are illustrated, and a distribution map is provided.

РЕЗЮМЕ. Описан новый род и вид жуков малашек трибы Apalochrini (Coleoptera: Malachiidae) Protopectinus pseudoparatinus gen. et sp.n., из Танзании в Западной Африке. Внешне вид близок к представителям евроазиатского рода Apalochrus Er. (бывший Paratinus Abeille de Perrin), но отличается присутствием гребешка над вторым члеником передних лапок самца. По этому признаку новый вид в трибе Apalochrini сравним с родом Protapalochrus Evers, у представителей которого специфичные структуры самцов не выражены. От них новый вид отличается следующими признаками: усики слегка пильчатые, 1 и 2 членики лапок увеличены по сравнению с остальными, передние голени слегка расширены дистально, а средние голени вздуты и уплощены по внутренней стороне, несущей протоки желез феромонов. На основании указанных признаков описан новый род - Protopectinus gen.n. Даны иллюстрации внешнего вида, специфичных структур и гениталий самца, показано распространение.

\section{Introduction}

The tribe Apalochrini represents soft-winged flower beetles with typical antennae possessing extremely small second antennomere, which is round or oval, usually almost completely hidden by the scape making the antennae appear10-segmented. SE Asia, Africa and Australia are the regions of the highest species diversity of the tribe with a wide spectrum of species male characters, which are, used to define different taxa.

Apalochrini material from different regions of Africa was purchased at the 1995 Prague Entomological Fair (Insektenbörse). Amongst this, a series of beetles attracted attention due to similarity of external appearance with species of Apalochrus Erichson, 1840 (that

How to cite this article: Tshernyshev S.E. 2020. Protopectinus pseudoparatinus - a new genus and species of soft winged flower beetle of the tribe Apalochrini (Coleoptera: Malachiidae) from East Africa // Russian Entomol. J. Vol.29. No.1. P.69-72. doi: 10.15298/rusentj.29.1.09 
were formerly attributed to the genus Paratinus Abeille, 1891, a junior synonym of Apalochrus [Mayor, 2003]). This required more detailed investigation because of all known Apalochrus species were found only in Eurasia [Tshernyshev, 2015]. In fact, the beetles from Africa are not congeners of Apalochrus, because of male possesses a comb above the second tarsomere in anterior legs, thereby these species should be attributed to the genus Protapalochrus Evers, 1987. The main and the only external character allowing differentiation of Apalochrus and Protapalochrus is tarsal comb on second tarsomere on anterior legs in male. When describing Protapalochrus Evers reasoned generic status by simple male morphology, almost completely lacking special characters, excepting a comb above the second tarsomere in anterior legs: "Protapalochrus nov. gen. Das 2. Fülerglied ist im 1. Fühlerglied versteckt. Das 2. Glied der Vordertarsen beim 5 mit einer uber dem 3. Glied ragenden Tarsalklammer. Mittelbeine einfach (ohne Excitatoren)." [Evers, 1987: 13].

The genus Protapalochrus was recently reviewed [Tshernyshev, 2016] with special attention to species distribution, because species with tropical distribution were included in the genus, although type species, Apalochrus flavolimbatus Mulsant et Rey, 1853, is limited to the Palaearctic Region from North Africa to East Europe. All species of typical Protapalochrus occur in Palaearctic [Tshernyshev, 2016], and the taxonomic position of those distributed in Africa is still unclear.

Detail study of the male in the series of beetles from Africa purchased in Prague presented new characters allowing differentiation from the genus discussed above, namely: intermediate tibiae swollen and flattened inwardly and anterior ones widened distally, antennae dentate, aedeagus widened at about middle and stretched distally. Tarsi also look specific due to enlarged 1st and 2nd tarsomeres and a claw-segment elongate and narrow in all legs. These facts indicate this new species as a member of separate genus, which is described below as Protopectinus pseudoparatinus Tshrernyshev gen. et sp.n.

The beetles were studied using an Amscope trinocular stereomicroscope (Ultimate Trinocular Zoom Microscope 6.7X-90X Model ZM-2TY) and digital photographs were taken using a Carl Zeiss Stemi 2000 trinocular microscope and the AxioVision programme. Male genitalia, embedded in DMHF (Dimethyl hydantoin formaldehyde), were mounted onto a transparent card and pinned under the specimen. Specimens have been deposited at the author's collection ( $\mathrm{SCH})$, which is kept in the Institute of Animal Systematics and Ecology, Siberian Branch of the Russian Academy of Sciences, Novosibirsk, Russia.

\section{Protopectinus Tshrernyshev, gen.n.}

Type species: Protopectinus pseudoparatinus Tshrernyshev, sp.n., fixed by monotypy in the present paper.

DIAGNOSIS. Diagnosis is based on male special characters only. Size small to moderate (about 2.6-2.9 mm) softwinged flower beetles with the body elongate, parallel and very weakly expanded posteriorly. Upper side metallic blue- bronze and underside black-brown, antennae, tibiae and tarsi of anterior and intermediate legs, and bases of tibiae in posterior legs yellow-brown. Antennae filiform with dentate intermediate antennomeres, $5^{\text {th }}-10$ th antennomeres triangular with slightly elongate outer edges, 4 th antennomere oval the same length and width as the 3rd, antennae long, 0.4 times as long as body, extending beyond the base of elytra. Head small and flat, narrower than pronotum, eyes simple, not large, slightly protruding. Pronotum transverse, with evenly rounded angles, slightly pronounced anteriorly and straight posteriorly and with distinct margination of sides; disc depressed at the base, with posterior margin elevated and swollen. Elytra parallel, very weakly expanded at apical fourth, densely and coarsely punctured, with small and weakly protruding shoulders, apices evenly rounded, simple, suture distinctly marginate and slightly elevated, curving over apices of elytra forming weak depression in a corner possessing short white adpressed hairs. Anterior tarsi with small transverse comb above the 2 nd segments, $1^{\text {st }}$ and $2^{\text {nd }}$ tarsomeres in anterior and intermediate legs twice as large as those of posterior; intermediate tibiae widened distally, slightly swollen and with flattened area internally, anterior tibiae slightly widened distally, simple, femora in all legs simple, slightly flattened.

Metathorax evenly swollen and bituberculate, lacking appendage or tuft of hairs. Pygidium undivided, evenly rounded and narrowed distally, with straight distal side; lateral lobes of the 8th ultimate abdominal ventrite distinctly adjoined, narrowed distally, with round emargination in middle; aedeagus slightly curved dorsally, strongly widened at about the middle, with stretched elongate evenly narrowed and slighlty downwardly curved lamella; bristles or denticles are not visible in the inner sac. Tegumen narrow, elongate, with long thin parameres.

Species of the genus is similar to representatives of Protapalochrus and differs in the swollen and flattened inwardly intermediate tibiae, dentate antennae, and aedeagus widened at about middle and distally elongate.

ETYMOLOGY. The name of the genus is a combination of two words: Proto- is Greek $\pi \rho \omega$ бo $\varsigma$, the first, and Pectinus - is a name of the genus proposed by Evers to African species formerly attributed to Apalochrus, but possessing a comb in anterior tarsi.

NOTES. Species of the genus is distributed in East Africa and is known from Tanzania only.

\section{Protopectinus pseudoparatinus Tshrernyshev, sp.n.} Figs 1-11.

MATERIAL. Tanzania East: Holotype, $\sigma^{r}$, Coast Region, Utete, Rufiji River, Kindwitwi Guest House, $8^{\circ} 00^{\prime}$ S; 38 $38^{\circ} 46^{\prime} \mathrm{E}$; 10 14.XII.1993, M. Snizek leg.; paratypes, $30^{\top} \sigma^{\top}$, 9 우, , idem.

DESCRIPTION. Holotype, male (Figs 1-2). Body elongate, parallel, not wide, very slightly expanded posteriorly.

Antennae, palpi, tibiae and tarsi in anterior and intermediate legs, basal part of posterior tibiae, distal parts of coxae, edges of ventrites yellow-brown, other body parts blackbrown; upper surface of head, pronotum and elytra with green-bronze metallic lustre. Surface evenly covered with semi-erect light or white pubescence, locally with single long thin erect hairs. Vesicles pale yellow, and thoracic mesepimera black.

Head slightly narrower than pronotum, flat, not impressed; eyes slightly protruding, small, round, frons flat; genae short and straight; clypeus narrow, transverse, straight; labrum narrow, transverse; palpi simple with apical segment wide and securiform; surface of head shining, densely and coarsely punctured 


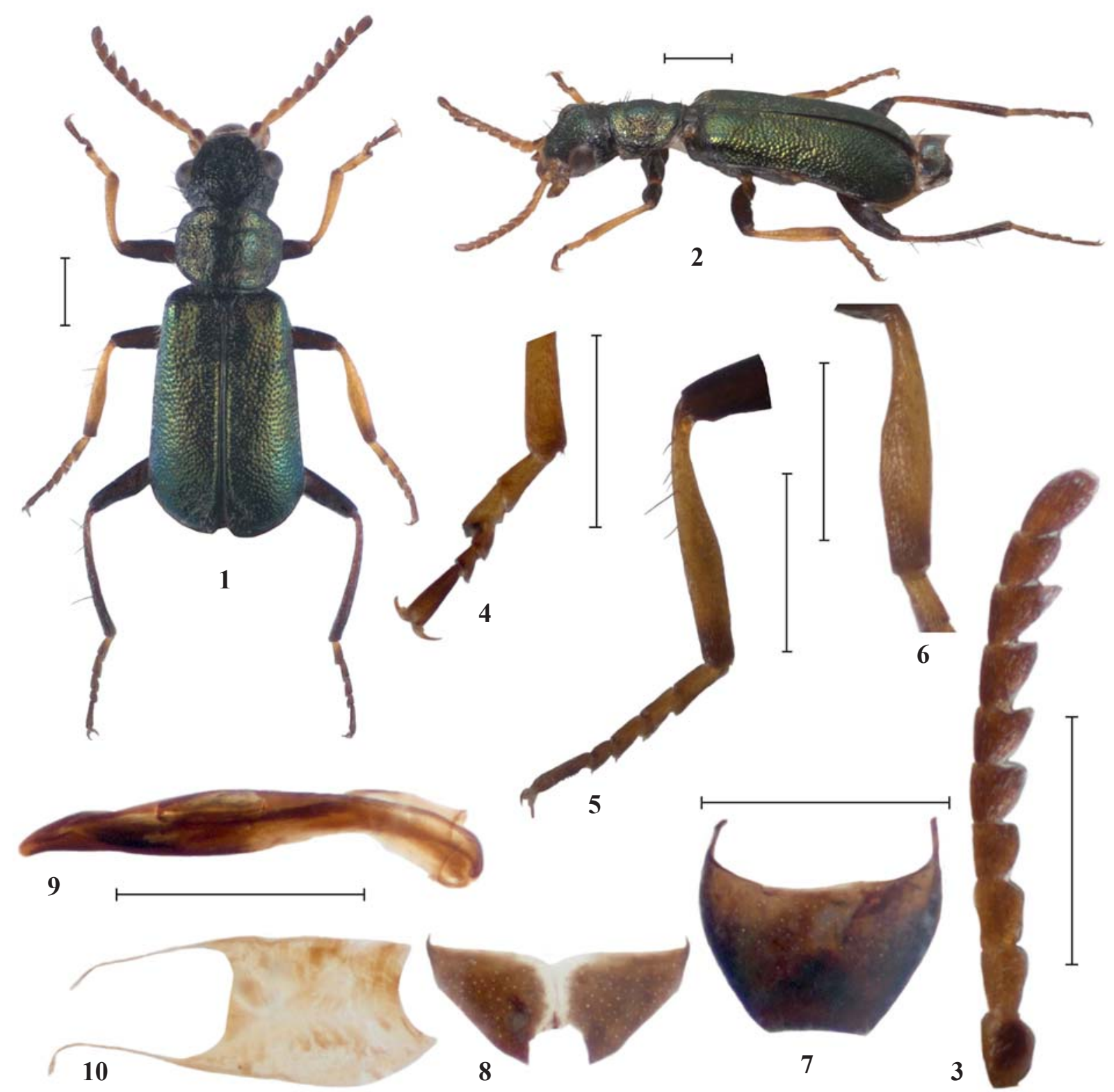

Figs 1-10. Protopectinus pseudoparatinus Tshrernyshev gen. et sp.n., holotype, male: 1 - external appearance, dorsal view; 2 external appearance, lateral view; 3 - left antenna; 4 - left anterior tarsus; 5 - tibia and tarsus of left intermediate leg; 6 - femur of right intermediate leg; 7 - pygidium; 8 - ultimate abdominal ventrite; 9 - aedeagus, dorsal view; 10 - tegmen. Scale bars: 0.5 mm.

Рис. 1-10. Protopectinus pseudoparatinus Tshrernyshev gen. et sp.n., голотип, самец: 1 - внешний вид, дорзально; 2 - внешний вид латерально; 3 - левый усик; 4 - левая передняя лапка; 5 - голень и лапка левой средней ноги; 6 - бедро правой средней ноги; 7 - пигидий (апикальный тергит); 8 - восьмой терминальный абдоминальный вентрит (апикальный стернит); 9 - эдеагус, дорзально; 10 - тегмен. Масштаб: 0,5 мм.

and wrinkled behind forehead, with indistinct microsculpture, sparsely covered with fine semi-erect pubescence.

Antennae dentate, $1.3 \mathrm{~mm}$ long, extending beyond the base of elytra (Fig. 3); 1st antennomere oval, wide, $2^{\text {nd }}$ small, round almost completely hidden by the $1^{\text {st }}, 3^{\text {rd }}$ antennomere triangular, elongate, $4^{\text {th }}$ antennomere oval and the same length and width as the $3^{\text {rd }}, 5^{\text {th }}$ antennomere 1.5 times as long as $4^{\text {th }}$, $5^{\text {th }}-10^{\text {th }}$ antennomeres triangular with slightly extended outer edges, apical antennomere oval, as long as $3^{\text {rd }}$ antennomere; surface sparsely covered with short, light pubescence.

Pronotum transverse with evenly rounded angles, not narrowed apically, strongly impressed near base with posterior margin elevate and swollen; slightly produced anteriorly and straight posteriorly; margination of sides distinct; surface densely and coarsely punctured, with indistinct microsculpture, shining, evenly covered with fine curved semierect light pubescence and sparse long dark erect hairs.

Scutellum trapezoid, distinct and narrow, transverse and adpressed, evenly punctured and covered with fine pubescence, sides with thin margin.

Elytra parallel, very slightly widened at the apical fourth, at base slightly wider than pronotum; humeri small, slightly protruding; apices evenly rounded, simple; disc distinctly marginate on external sides, suture wide, slightly elevate, the edging continues to elytral apices and forming impressed angle covered with short white adpressed pubescence; sur- 


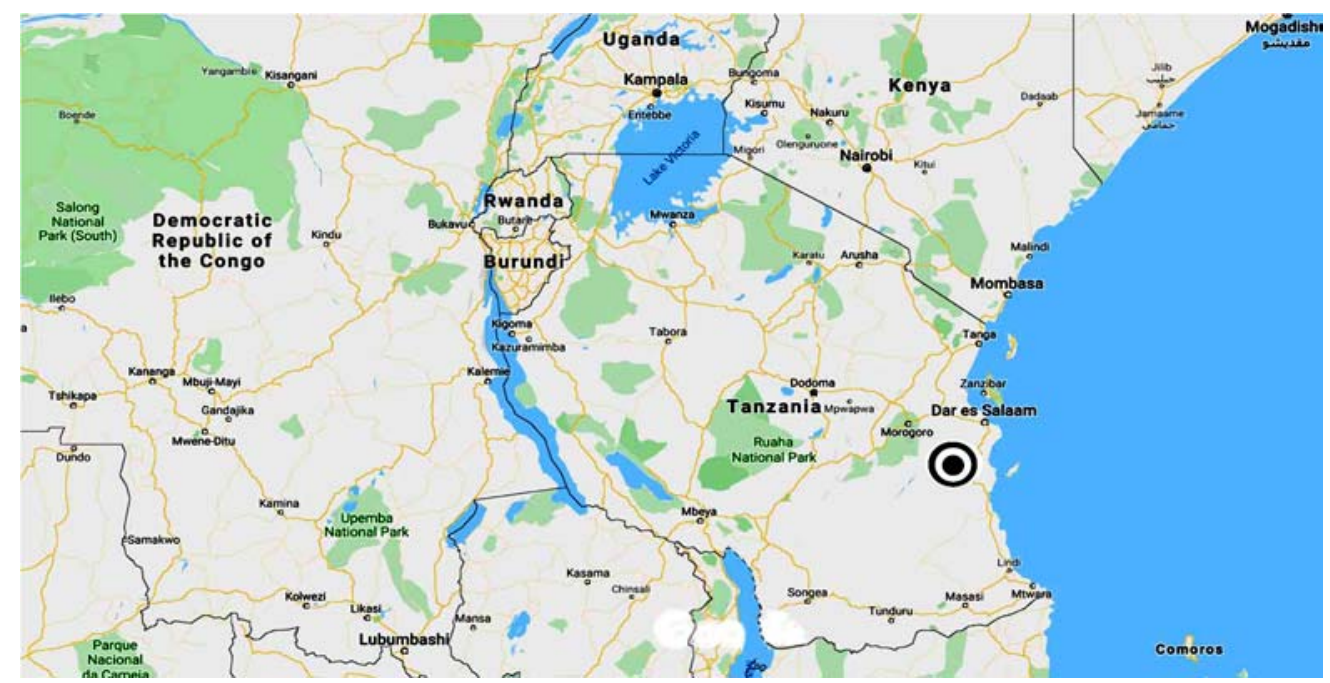

Fig. 11. Protopectinus pseudoparatinus Tshrernyshev gen. et sp.n., distribution map.

Рис. 11. Protopectinus pseudoparatinus Tshrernyshev gen. et sp.n., карта распространения.

face shining, densely and coarsely punctured, with distinct microsculpture, sparsely covered with thin white semi-erect pubescence.

Hind wings normally developed.

Legs short and strong; posterior femora extend beyond elytral apex; anterior tibiae widened distally, simple (Fig. 1), intermediate tibiae evenly stout to distal part and flattened in apical 2/3 in internal side (Figs 5-6); posterior tibiae simple, thin, straight, femora slightly flattened; all tarsi 5-segmented, slightly compressed, not long, 2nd segment in anterior tarsi with a short comb above; 1 st and 2 nd tarsomeres are equal in size and each twice as large as 3rd or 4th tarsomeres, clawsegment as long as 1 st and 2 nd tarsomeres together and half as wide in all legs; claws short, thin, narrow, with small denticles at base.

Ventral body surface sparsely punctured, dull, evenly covered with fine, adpressed white pubescence; metathorax swollen, bituberculate, lacking appendage of hair tuft. Pygidium undivided, evenly rounded and narrowed distally, with straight distal side (Fig. 7); lateral lobes of the 8th ultimate abdominal ventrite distinctly adjoined, narrowed distally, with round emargination in middle (Fig. 8); aedeagus slightly curved dorsally, strongly widened at about the middle, with stretched, evenly narrowed and slightly downcurved lamella; bristles or denticles are not visible in the inner sac (Fig. 9). Tegmen narrow, elongate, with long thin parameres (Fig. 10).

Length $2.7 \mathrm{~mm}$, width (at elytral base) $0.8 \mathrm{~mm}$.

Female somewhat longer, anterior palpomere narrower, antennae much shorter, 1 st and 2 nd tarsomeres as wide as the other tarsomeres, not enlarged, $2^{\text {nd }}$ tarsomere lacking comb; elevated edging of suture is restricted before elytral apices. Length 2.9-3.0 mm, width (at elytral base) $0.9 \mathrm{~mm}$.

ETYMOLOGY. The name of the new species is taken from the name of genus Paratinus (currently a synonym of Apalochrus), which species are common in European steppes and look similar to a new species.

DISTRIBUTION. Known from type locality only, Tanzania: Coast Region (Fig. 11).

Acknowledgements. The author is grateful to Jon Cooter (Oxford University Museum of Natural History, UK) for his kind help with the linguistic revision of the text.

This study was supported by the Federal Fundamental Scientific Research Programme for 2013-2020, grant No. VI.51.1.5 (AAAA-A16-116121410121-7).

\section{References}

Evers A.M.J. 1987. Synopsis der Gattung Apalochrus Er. und der verwandten Gattungen der Welt (Col., Malachiidae). 63. Beitrag zur Kenntnis der Malachiidae // Annalen Zoologische Wetenschappen. Bd.253. S.1-73.

Mayor A.J. 2003. Nomenclatorial corrections for Dasytidae and Malachiidae (Coleoptera) // Insecta Mundi. Vol.17. Nos 1-2. P.85-96.

Tshernyshev S.E. 2015. A review of species of the genus Apalochrus Erichson (Coleoptera, Malachiidae) // Zootaxa. Vol.3941. No.3. P.358-374. http://dx.doi.org/10.11646/zootaxa.3941.3.3.

Tshernyshev S.E. 2016. A review of species of the genera Protapalochrus Erichson and Paratinoides L. Medvedev (Coleoptera, Malachiidae) // Zootaxa. Vol.4139. No.3. P.369-390. 